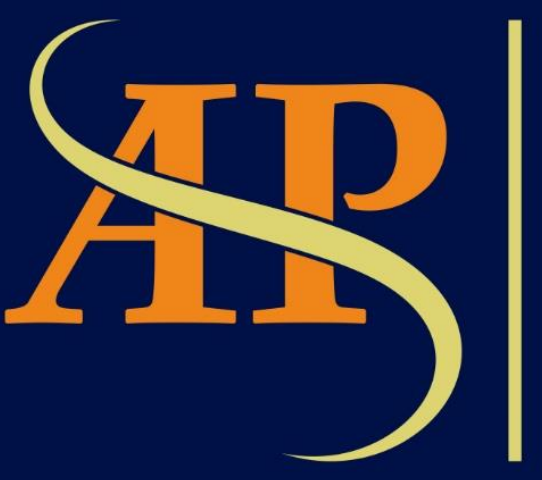

JURNAL

ASIA

PACIFIC

STUDIES

Journal of International Relations Study Program Faculty of Social and Political Sciences

Universitas Kristen Indonesia

Volume I | Number 2 | July - December 2017 


\title{
JUSTIFIKASI INTERVENSI INTERNASIONAL DALAM KONFLIK SUATU NEGARA
}

\author{
Andaru Satnyoto \\ Hubungan Internasional, Fakultas Ilmu Sosial dan Ilmu Politik, Universitas Padjadjaran Bandung \\ andarusatnyoto@gmail.com
}

\begin{abstract}
Conflict among states or interstate conflict is still part of the important concern in the politics and international relations. International attention is becoming stronger along with the shift view of international society regarding the intervention justification to reduce the conflict. Realist and moralist perspective are changed by cosmopolitan one since the individual interest and security are more important rather than the will to maintain the state security including motives of sphere of influence and maintaining group stability and balance of power. This post-cold war phenomenon on the intervention justification tends to be conducted in the multilateral way and it is urged by humanity reasons - that is why it is called humanitarian intervention -- rather than political and state security reasons. The significance of intervention in the international relations is debatable issue since it involves various matter like legalistic language/term, various interests and international opinion.
\end{abstract}

Keywords: intervention, justification of intervention, humanitarian intervention, cosmopolitan perspective

\begin{abstract}
Abstrak
Konflik antar negara (inter-state conflict) menjadi perhatian penting dalam politik dan hubungan internasional. Perhatian internasional menjadi semakin kuat dengan adanya pergeseran pandangan masyarakat internasional terkait justifikasi intervensi untuk meredam konflik. Perspektif realis dan moralis digeser oleh (perspektif kosmopolitan) mengingat kepentingan dan keamanan individu lebih penting daripada keinginan untuk mempertahankan keamanan negara termasuk motif-motif lingkungan pengaruh, mempertahankan stabilitas kelompok dan perimbangan kekuasaan. Justifikasi intervensi yang merupakan fenomena perang dingin cenderung dilaksanakan dengan cara multilateral dan didorong oleh alasan-alasan kemanusiaan - itulah mengapa disebut dengan intervensi kemanusiaan (humanitarian intervention) - daripada alasan politik dan keamanan negara. Signifikansi intervensi dalam hubungan internasional merupakan isu yang diperdebatkan karena melibatkan berbagai hal seperti pengertian legalistik, berbagai kepentingan dan opini internasional.
\end{abstract}

Kata kunci: intervensi, justifikasi intervensi, intervensi kemanusiaan, perspektif kosmopolitan 


\section{Pendahuluan}

Pada akhir tahun 1989, hubungan internasional memasuki babak baru, ditandai adanya peredaan persaingan antara Uni Soviet dengan Amerika Serikat. Suasana ketegangan perang dingin (cold war) antara Blok Barat kelompok Amerika Serikat dan sekutunya berhadaphadapan dengan Blok Timur dipimpin Uni Soviet dan sekutunya khususnya beberapa negara Eropa Timur dapat dikatakan berakhir tahun 1990, yang ditandai dengan penarikan pasukanpasukan Soviet dari Eropa Timur, Jerman Timur, dan bubarnya Uni Soviet, yang kemudian sebagai entitas negara diwarisi oleh Rusia saat ini. Pasca situasi ini ada harapan besar tumbuhnya perdamaian yang lebih baik di dalam masyarakat internasional.

Harapan ini tampaknya tidak berlebihan, karena sejak akhir Perang Dunia II 1945, ada semacam kelegaan bahwa dunia seolah tidak lagi dibayangi oleh kemungkinan timbulnya perang Blok Barat dan Blok Timur. Dengan hilangnya ancaman perang pasca perang dingin ini, dibayangkan bahwa kemudian kegunaan militer berkurang, anggaran untuk militer di banyak negara juga akan berkurang dan lebih banyak untuk pembangunan. Inilah yang kemudian dikatakan bahwa pasca perang dingin negara-negara di dunia akan mendapatkan keuntungan atau dividen perdamaian (peace dividend). Dunia juga merasakan berkurangnya ancaman nuklir antara AS dan Uni Soviet. Ketegangan ke dua pihak ini sering dibayangi oleh ancaman nuklir, mengingat dua kubu tersebut memiliki ratusan bahkan diduga ribuan senjata nuklir yang dapat menghancurkan dunia ini. Walaupun ada juga yang menyatakan bahwa jika perang nuklir terjadi, hanya akan menimbulkan kehancuran bersama, sehingga ini menjadi semacam keseimbangan pengendalian "teror" agar tidak membuat perang nuklir. Perang nuklir demikian, menjamin kedua pihak atau siapapun hanya menuai kehancuran bersama (mutual assured destruction).

Namun demikian, sejak tahun 1990an ternyata juga muncul atau mungkin lebih tepat disebut lebih tampak mengemuka adanya masalah-masalah baru dalam penanganan konflik antar masyarakat negara dan juga internasional. Ada semacam perkembangan yang sangat dinamis dalam masyarakat dengan bentuk konflik-konflik yang lebih terbuka. Ada berbagai konflik yang makin terbuka, perang sipil, konflik intra state, dalam satu negara dan sejenisnya yang juga dipandang dapat mempengaruhi perdamaian dunia dan politik internasional. Konflikkonflik intra negara ini dapat bernuansa konflik etnik, klaim budaya, sejarah, perebutan kekuasaan ekonomi dan politik, maupun pemberontakan dan aspirasi pemisahan diri suatu kelompok atau etnik suatu negara, konflik yang terkait dengan terorisme, dan sebagainya. Konflik ini misalnya tampak dalam konflik Yugoslavia (konflik Balkan), Somalia, Kamboja, Haiti, Timor Timur / Timor Leste, Pemberontakan Kurdi, Bosnia Herzegovina, Serbia, Burundi, Mali, Pantai Gading, Republik Afrika Tengah, Rwanda, Burundi, Sudan, Suriah, Kongo, Sierra Leone, Nigeria, Irak, Afganistan dan lain-lain.

Konflik-konflik tersebut diatas yang umumnya terjadi dalam satu wilayah negara atau hanya di sekitar perbatasan satu atau dua negara, tidak terjadi serentak dan tidak sangat masif, sehingga secara sekilas tidak menghancurkan suasana perdamaian pada umumnya. Konflikkonflik dalam masyarakat demikian meskipun juga diwarnai dengan aksi-aksi kekerasan, tetapi tidak menyeret negara-negara lain terlibat dalam perang atau konflik tersebut. Namun demikian, konflik tersebut tetap masalah serius karena menimbulkan korban-korban manusia yang cukup banyak, sering timbul pengungsian mendadak dalam jumlah besar, pencabutan masyarakat dari akar tempat tinggalnya. Konflik demikian kemudian sering disebut sebagai bencana kemanusiaan.

Konflik-konflik tersebut mempengaruhi suasana masyarakat internasional atau politik internasional melalui berbagai cara atau model. Misalnya krisis tersebut memicu krisis kesehatan masyarakat, krisis pangan dan kelaparan dan pada gilirannya menimbulkan korban manusia. Konflik juga menimbulkan pengungsi-pengungsi yang mengalir ke negara-negara 
tetangga. Secara umum konflik yang meluas dapat menimbulkan apa yang umum disebut sebagai tragedi kemanusiaan, pengusiran penduduk lokal, pengusiran etnis, dan kehancuran infrastruktur publik. Dalam dekade tahun 1990-an saja konflik masyarakat demikian telah mengakibatkan ribuan orang terbunuh, 5,5 juta terdampak krisis kemanusiaan atau mengungsi. Konflik-konflik bersenjata pasca tahun 1990-an ini sangat bervariasi dan dinamis terkait dengan berbagai aspek antara lain: situasi internal negara, misalnya apakah banyak faksi-faksi terlibat yang sangat berbeda atau berlawanan, komposisi etnis warga negara atau penduduk, warisan sejarah dan lain-lain.

Masyarakat internasional, khususnya melalui organisasi-organisasi internasional seperti Perserikatan Bangsa-Bangsa dan organisasi internasional lainnya seperti Uni Eropa dan NATO (North Atlantic Treaty Organization) aktif mengambil langkah-langkah bantuan kemanusiaan (humanitarian assistance) sebagai modus ataupun alasan untuk melakukan intervensi ke dalam konflik suatu negara. Walaupun demikian dalam berbagai kasus seringkali masyarakat internasional belum mampu mencegah konflik secara efektif. Usaha-usaha ini seringkali disebut juga sebagai bagian upaya menjaga perdamaian dunia, perdamaian internasional secara menyeluruh.

Intervensi terhadap suatu negara, baik dalam kondisi konflik maupun dalam kondisi lainnya, tetap saja menimbulkan masalah dan perdebatan. Masalah ini berkaitan dengan pengertian dan keperluannya (signifikansi) intervensi atau dalam bahasa yang lebih legalistik justifikasi intervensi tersebut dalam tatanan hubungan internasional dewasa ini. Bagaimana justifikasi intervensi dalam tatanan hubungan internasional dewasa ini? Tentu alasan-alasan intervensi tidak sekedar alasan teoritis belaka, karena dalam praktek hubungan internasional bisa diduga banyak memiliki muatan-muatan kepentingan dalam argumen kebijakan maupun dalam tindakan atau perilaku hubungan antar negara (internasional).

\section{Perspektif Intervensi}

Istilah intervensi ini biasa dipergunakan dalam dunia politik internasional untuk menggambarkan kebijakan dan tindakan suatu negara yang mencampuri urusan negara lainnya yang jelas bukan urusannya. Pengertian yang lebih luas adalah setiap usaha mencampuri urusan pihak lain (negara lain) secara berlebihan dalam urusan politik, ekonomi, sosial dan budaya pihak lain. Cara-cara intervensi misalnya mengirim pasukan militer, melakukan embargo, melakukan blokade wilayah masuk ke negara lain. Pengertian ini memuat prinsip campur tangan satu pihak pada pihak lain, dengan berbagai cara.

Namun sejauh mana pengertian bahwa campur tangan itu dianggap secara berlebihan tidak dijelaskan, dan juga hal ini tampaknya tidak mudah untuk dirumuskan. Konsep non intervensi walaupun relatif umum digunakan dalam politik internasional dan hubungan internasional umumnya, namun sering tidak mudah dipahami karena istilah ini mengandung sifat muatan deskriptif maupun normatif. Konsep ini tidak semata hanya gambaran suatu peristiwa.

Dalam definisi atau pengertian bahasa Inggris relatif lebih tegas dan menyebutkan bahwa intervensi disamping dipergunakan dalam dunia politik, juga dipergunakan untuk bidang lain seperti intervensi sosial, intervensi alam medis atau kesehatan, intervensi dalam therapy psikologis dan lain-lain. Dalam politik berdasarkan ensiklopedia Wikipedia, pengertian intervensi merujuk pada beberapa tindakan untuk mencampuri urusan negara lain. Intervention may refer to interventionism (politics):1.Humanitarian intervention, an attempt to reduce suffering within a state through armed conflict. 2. Entente intervention in the Russian civil war 1918-1925. 3. Invasion or military offensive. Pengertian ini sejalan dengan definisi yang diberikan kamus Oxford yang menekankan campur tangan pihak lain terutama dengan adanya tindakan militer. Intervention as interfering or becoming involved, e.g. to prevent something 
happening: armed intervention by one country in the affairs of another. Istilah intervensi pada dasarnya merupakan tindakan campur tangan satu pihak terhadap pihak lain.

Seperti disampaikan diatas, dalam hubungan internasional dan politik internasional masalah intervensi bukanlah istilah baru, ia telah hadir bersamaan dengan timbulnya prinsip hukum antar negara yaitu prinsip kedaulatan nasional dan prinsip non interference atau tidak mencampuri urusan dalam negeri negara perjanjian. Makna pokok prinsip kedaulatan selama ini adalah gagasan yang menyatakan bahwa tidak ada kekuasaan yang sah di atas negara, kecuali negara tersebut secara sukarela menyerahkannya kedaulatan kepada pihak lain atau organisasi internasional sesuai perjanjian internasional yang disepakati. Sedang prinsip non interference sebagai basis untuk non intervensi yaitu prinsip tidak mencampuri urusan dalam negeri negara lain. Disamping itu dalam etika internasional juga merujuk kepada dua aspek politik atau otoritas. Secara internal atau ke dalam menunjukkan adanya kewenangan politik dan legal untuk bertindak apa pun yang sah dalam batas-batas negara. Negara memiliki hakhak untuk mengatur urusan dalam negerinya, dibiarkan atau dibolehkan untuk bebas mengelola “community's internal affairs" sendiri. Namun pada sisi lain juga mempunyai kewajiban untuk tidak mencampuri urusan negara atau masyarakat lainnya. Kedaulatan secara eksternal adalah kewenangan negara untuk melakukan kebijakan dan tindakan dalam menjalankan relasi dengan negara lain atau dengan pelaku hubungan internasional lainnya. Pengertian intervensi dapat secara umum merujuk pada "external action that influence the domestic affairs of another sovereign state", yang mana hal ini dapat memiliki arti yang luas. Pemahaman yang lebih sempit biasanya merujuk langsung penggunaan kekerasan (forcible action / interference) ke dalam urusan domestik negara lain.

Jadi dalam pengertian intervensi yang luas dapat mencakup aspek yang relatif lunak maupun yang keras dengan kekuatan senjata atau militer. Intervensi dapat bersifat lunak seperti dalam bentuk himbauan, pernyataan saran oleh satu pemerintahan negara kepada negara lain hingga bentuk-bentuk yang lebih mendesak, menuntut dengan keras bahkan juga bisa dengan alat-alat kekerasan seperti penggunaan kekuatan militer. Pada posisi intervensi lunak (low intervention) antara lain dapat berupa pidato atau pernyataan (speeches), penyiaran, termasuk propaganda radio, televisi dan lainnya (broadcast), bantuan ekonomi (economic aid), dan bantuan militer (military advisors), pada awal intervensi Amerika Serikat di Vietnam misalnya, lebih berupa bantuan-bantuan ekonomi, propaganda dan bantuan penasihat-penasihat militer, baru kemudian invasi militer. Sedang yang cenderung keras antara lain: mendukung kelompokkelompok oposisi, dan blokade wilayah, blokade perdagangan dan sebagainya. Sedangkan intervensi yang keras dapat mencakup penggunaan tindakan atau operasi militer terbatas (limited military action), seperti misalnya tindakan AS membom Libya tahun 1986 yang dituduh mendukung terorisme. Tindakan intervensi paling keras umumnya merupakan tindakan operasi militer penuh dan pendudukan (full scale military invasion dan occupation) suatu wilayah atau negara seperti Uni Soviet menduduki Hungaria, 1956, Czechoslovakia 1968 dan Afghanistan 1978-1988; Amerika Serikat menginvasi Vietnam 1963-1975, Grenada, 1983, Panama 1989, Vietnam menginvasi Kamboja 1979, Tanzania menginvasi Uganda 1979 dan lain-lain. Jadi pengertian dan makna intervensi dapat bersifat luas dari campur tangan yang cenderung lunak bahkan sepertinya tidak tampak seperti terlihat dalam model-model bantuan sosial ekonomi, hingga campur tangan dengan kekerasan bersenjata, terorganisasi, masif mencakup sebagian atau menyeluruh meliputi semua wilayah negara. Secara diagramatik dari yang lunak ke yang keras campur tangan negara terhadap negara lain dapat diurutkan sebagai berikut: 


\section{Low Coercion \\ (High local choice)}

: - speeches (pernyataan/pidato)

- broadcast (siaran/propaganda)

- economic aid (bantuan ekonomi)

- military advisors (bantuan penasihat militer)

- support opposition (bantuan terhadap oposisi)

- blockade (blokade teritorial)

- limited military action (tindakan/perang terbatas)

- military invasion (perang/invasi militer)
High Coercion

(Low local choice)

Dari pemikiran di atas dan arah alat yang dipergunakan, intervensi dapat pula dibedakan atau dikategorikan dalam dua kategori yaitu intervensi militer dan non militer. Intervensi non militer bisa dalam bentuk-bentuk yang tradisional sebagai cara halus untuk mempengaruhi hingga usaha kemanusiaan yang lebih merupakan usaha memberikan pertolongan, yang sering disebut sebagai humanitarian intervention. Humanitarian intervention ini seperti nampak dalam bentuknya misalnya pengiriman obat-obatan dan dokter yang melayani korban, bantuan pangan dan alat-alat keselamatan dan lain-lain. Intervensi kemanusiaan umumnya dianggap non forcible intervention, menekankan pada tindakan-tindakan damai (pacific) dari negara, gabungan negara-negara / multilateral, organisasi internasional dan lembaga-lembaga swadaya masyarakat (NGO) untuk mediasi dan resolusi konflik serta rekonstruksi kondisi masyarakat.

Dari segi waktu kadang intervensi militer dan non militer hadir bersamaan atau salah satu lebih dahulu. Hal ini terjadi karena biasanya intervensi kemanusiaan terjadi karena telah ada banyak korban dalam suatu konflik. Kadang kala intervensi kemanusiaan tidak cukup sehingga akhirnya memaksa perlu adanya intervensi militer atau intervensi kemanusiaan baru bisa berlangsung setelah ada intervensi militer untuk menciptakan situasi kondusif bagi efektivitas pertolongan. Walaupun demikian intervensi kemanusiaan dapat saja terjadi tanpa ada intervensi militer, karena situasi dalam masyarakat konflik telah kondusif damai dan telah berlangsung proses rekonsiliasi.

Oleh karena itu, ada yang menyebut bahwa kehadiran militer dan tindakan kemanusiaan (humanitarian intervention) pada dasarnya merepresentasikan dua sisi lain dari satu koin yang sama; yaitu ketidakmampuan manusia untuk menyelesaikan konflik secara damai. Jadi sebenarnya humanitarian intervention pun dapat terjadi juga bersamaan dengan melibatkan kekuatan militer (bersenjata) dari satu atau beberapa negara, organisasi internasional regional dan global seperti PBB (Perserikatan Bangsa-Bangsa).

Secara teoritis terdapat berbagai pandangan terhadap masalah intervensi, antara lain pandangan realist, cosmopolitan dan state moralist. Bagi kaum realist, salah satu nilai utama dalam politik internasional adalah terbentuknya ketertiban dan perdamaian (peace and order) dengan melalui suatu sistem perimbangan kekuatan (balance of power). Bagi kaum realis intervensi dapat dibenarkan atau dapat diterima sepanjang untuk keperluan memelihara keseimbangan kekuatan dan menjaga ketertiban. Hal ini pernah terjadi pada masa lalu, pada masa perang dingin misalnya, Uni Soviet seolah merasa berhak untuk melakukan intervensi ke Eropa Timur. Dengan intervensi demikian tampaknya diterima sebagai usaha menjaga ketertiban dan diharapkan dapat mencegah kemungkinan timbulnya perang yang lebih besar dengan Blok Barat akibat kekacauan yang tidak terkendali. Intervensi yang semata-mata invasi adalah pelanggaran kedaulatan. Oleh karena itu negara harus kuat, mampu mempertahankan diri, atau bergabung (koalisi) untuk bersama-sama menghadapi musuh.

Berbeda dengan kaum realist, kelompok kosmopolitan terutama mengarahkan pandangannya kepada masyarakat sebagai individu. Nilai utama bagi kaum kosmopolitan adalah keadilan (justice) dan lembaga kuncinya adalah masyarakat individu. Oleh karena itu 
menurut kelompok intervensi dapat diterima bila untuk mempromosikan atau melindungi keadilan individu masyarakat. Pada masa perang dingin kelompok kosmopolitan terbagi dua yang cenderung dianggap kiri (leftist) mendukung intervensi internasional terhadap pemerintahan korup, absolutik / tidak demokratis, penindasan. Sedangkan kelompok kanan adalah kelompok yang setuju terhadap upaya-upaya penggulingan pemerintahan prokomunis yang dianggap tertutup dan otoriter, pelanggar hak-hak asasi manusia (HAM). Walaupun pasca perang dingin relatif perbedaan ini telah menipis atau tidak ada, dan mereka menerima intervensi terhadap negara-negara yang menindas HAM masyarakatnya, tidak demokratis dan otoriter. Kelompok kosmopolitan menyatu dengan menekankan aspek perlindungan kemanusiaan.

Sedangkan kelompok state moralist, memandang bahwa nilai utama dalam politik internasional adalah otonomi negara dan rakyatnya. Dalam perspektif ini lembaga utamanya adalah negara-negara dengan aturan-aturan tertentu dan hukum internasional. Prinsip yang sering ditekankan adalah prinsip non intervensi suatu negara atau negara-negara terhadap kedaulatan dan wilayah negara lainnya. Oleh karena itu, intervensi tidak dapat dibenarkan. Dan sebaliknya kekuatan militer dan perang digunakan untuk mempertahankan integritas teritorial dan mempertahankan kedaulatan negara dari agresi negara lain.

\section{Pergeseran Pandangan dan Justifikasi Intervensi}

Sebagaimana disampaikan di depan bahwa, sejak berakhirnya perang dingin (cold war), pada akhir 1989 atau awal 1990-an, perhatian terhadap perang sipil, konflik intra negara menjadi lebih besar. Apalagi konflik-konflik internal negara juga lebih mengemuka, lebih menonjol, walaupun konflik internal negara bukanlah merupakan fenomena baru. Secara garis besar dalam sejarah konflik-konflik terkait dengan kontestasi dan persaingan masyarakat dalam negara terdapat 4 (empat) kemungkinan: Pertama, sebagai dampak dari perkembangan imperialisme, industrialisasi, komunikasi massa, nasionalisme dan ideologi yang tumbuh pada pertengahan abad ke-19. Kedua, konflik-konflik internal yang terjadi pada masa akhir perang dunia kedua hingga tahun 1960-an sebagai akibat hancurnya atau berakhirnya kekuasaan kolonial negara-negara Eropa di kawasan Asia dan Afrika. Pada masa ini tumbuh negara-negara baru yang belum sepenuhnya stabil, penuh gejolak. Kondisi ini juga bersamaan menguatnya kontestasi dan perebutan pengaruh Blok Barat - liberalisme dan Blok Timur, sosialismekomunisme. Ketiga, adalah masa pasca perang dingin, tahun 1990-an, yang ditandai menurunnya atau hilangnya konflik perebutan pengaruh Uni Soviet dengan AS. Dengan hilangnya pengaruh tersebut, konflik-konflik internal tidak terlalu dikhawatirkan meluas sebagai konflik global, karena konflik lokal atau internal tidak dimanfaatkan sebagai ajang untuk konflik dominasi kekuatan besar. Konflik-konflik pada masa ini hingga sekarang juga berlanjut terkait dengan pilihan-pilihan masyarakat menuju jalan demokrasi. Peristiwa terkini adalah apa yang disebut dengan Arab Spring, yaitu berkembangnya semangat perubahan demokrasi di negara-negara kawasan Timur Tengah yang semula banyak pemerintahannya tidak demokratis. Keempat, konflik antar negara dan intra negara terkait dengan merebaknya kekuatan terorisme di banyak negara. AS mencoba untuk bertindak sebagai pemimpin dunia memerangi terorisme, bahkan hingga menyerbu negara-negara lain, seperti di Irak dan Afganistan. Konflik terkait terorisme juga banyak berkembang di Afrika seperti Afrika Tengah, Nigeria, dan lain-lain.

Konflik-konflik yang melibatkan konflik internal negara dapat menjadi perhatian internasional. Faktor tersebut terkait beberapa hal, antara lain: biasanya ada aktor-aktor konflik yang memiliki pengaruh dan hubungan luar negeri, konfliknya menimbulkan banyak korban, menjadi tragedi kemanusiaan, perpecahan negara seperti Yugoslavia (konflik Balkan), dan Sudan, atau karena dugaan keterkaitan dengan terorisme. Adanya konflik-konflik ini 
mendorong usaha-usaha internasional untuk mengurangi korban dan mencegah korban lebih banyak, termasuk korban pengusiran dari tempat tinggalnya semula. Oleh karena itu intervensi ini sering disebut sebagai intervensi non-ideologi, dan lebih murni sebagai tindakan kemanusiaan atau humanitarian intervention. Oleh karena itu konflik internal pun bisa sangat mempengaruhi kondisi politik internasional. Dengan demikian makin memperkuat kondisi tiadanya batas-batas persoalan politik dalam negeri dengan politik internasional umumnya.

Sebagaimana disebut diatas, berakhirnya perang dingin juga ternyata membawa dorongan untuk lebih mempromosikan hak-hak azasi manusia, demokrasi dan lingkungan hidup di seluruh dunia. Hal ini makin mendorong isu-isu politik internasional yang lebih variatif dan luas, termasuk kemungkinan intervensi kemanusiaan terhadap konflik-konflik yang berlarut-larut. Ada dorongan kuat agar konflik-konflik yang menimbulkan banyak korban segera diintervensi demi menyelamatkan banyak nyawa. Persoalan bergeser dari isu kedaulatan ke isu kemanusiaan. Hal ini tampak misalnya dalam konflik-konflik di Afrika, Yugoslavia, Timor Leste pada waktu pemisahan diri dari Indonesia, yang kini di Suriah dan lain-lain. Konflik-konflik tersebut dinilai merusak nilai-nilai kemanusiaan dan penyelesaian masalah secara damai atau beradab. Konflik-konflik tersebut juga menimbulkan keprihatinan dunia internasional. Contoh-contoh konflik dan intervensi internasional misalnya: 1. Masalah Irak utara, pemberontakan masyarakat Kurdi telah menimbulkan ribuan pengungsi. PBB mewajibkan Irak membuka akses bantuan kemanusiaan internasional kepada pengungsi dan penerimaan kontingen pengamanan internasional dengan mandat PBB yaitu: United Nations Guard Contingent in Iraq (UNGCI), mulai 17 April 1991, dipimpin pasukan AS; 2. Konflik Bosnia Herzegovina 1992-1995. Sebagai kelanjutan konflik perpecahan Yugoslavia terjadi perang sipil di Yugoslavia, kemudian PBB membentuk pasukan intervensi untuk mengurangi dan mencegah korban sipil dengan membentuk United Nations Protection Force (UNPROFOR); 3. Konflik Somalia yang melibatkan berbagai kelompok kekuatan bersenjata antar masyarakat yang brutal, bahkan juga melibatkan anak-anak sedangkan pemerintah tidak berdaya (gagal) melindungi warganya. PBB membentuk penjaga perdamaian dan kemanusiaan yang dimotori AS dalam bentuk United Nations Task Force (UNITAF) melibatkan Pakistan, Malaysia dan lain-lain; 4. Konflik etnis di Rwanda antara kelompok Tutsi dan etnis Hutu, yang menimbulkan korban ratusan ribu orang. PBB membentuk pasukan keamanan internasional dibawah payung mandat United Nations Assistance Mission For Rwanda (UNAMIR), 1994.

Jadi sejak era pasca perang dingin konflik-konflik negara tidak lagi dilihat secara hatihati sebagai bagian konflik ideologis dan pengaruh negara besar, tetapi lebih dilihat problem kemanusiaan. Dengan demikian sejak masa ini intervensi kemanusiaan baik militer dan non militer menjadi lebih umum dan mendapat legitimasi secara internasional. Bahkan upaya intervensi ini sebagian juga mendorong keterlibatan organisasi negara-negara regional seperti negara-negara Afrika bersatu (OAU), NATO dan lain-lainnya. PBB membentuk pasukanpasukan perdamaian yang tidak lagi sekedar pasif, tetapi juga secara lebih jauh membekali mandat terhadap pasukan internasional untuk lebih aktif menjaga perdamaian dan tidak sekedar menjadi penengah, tetapi secara aktif "memaksa" semua pihak untuk melewati jalan damai, menjadi semacam peace enforcement mission.

Hal ini tampak misalnya dengan payung Bab VII Piagam PBB, Dewan Keamanan PBB secara aktif membuka peluang untuk embargo ekonomi dan senjata serta penggunaan kekuatan untuk memaksa penghentian pelanggaran HAM, seperti kasus Bosnia. Bahkan dalam kasus yang terkait Kosovo, NATO dipimpin AS melakukan intervensi dengan kekerasan di Yugoslavia / Serbia, untuk menghentikan pelanggaran HAM terhadap etnik tertentu seperti Albania, dan Bosnia dan memaksa Serbia berunding secara damai, dengan membombardir sasaran militer dan infrastruktur Serbia dari bulan Maret - Mei 1999. Hal ini makin menguatkan cara dan jalan (justifikasi) untuk intervensi kemanusiaan. 
Dalam berbagai kasus intervensi tersebut, memang mendapat tantangan dan gugatan dari kelompok penganut gagasan tradisional tentang hak kedaulatan negara dan prinsip non intervensi dalam hubungan internasional. Karena prinsip ini sudah menjadi norma dalam hubungan internasional menjadi terancam dan mengalami delegitimasi. Juga status serangan dalam suatu intervensi menjadi perdebatan dan dianggap pelanggaran hukum perang, karena para pihak tidak terlibat dalam situasi perang dan juga tidak ada pernyataan internasional sebagai adanya suatu perang.

Namun demikian, tampaknya para pemimpin dunia makin menyepakati atau sekurangnya memahami kebutuhan intervensi kemanusiaan. Dalam "United Nations Millennium Assembly" (Sidang Umum PBB Millennium Baru) di New York, September 2000, pada dasarnya ada semacam kesepahaman untuk membenarkan adanya humanitarian intervention dan peran PBB yang lebih signifikan dalam mengatasi masalah-masalah konflik baik internal maupun internasional yang membahayakan perdamaian dan kemanusiaan. Bahkan Lahkdar Brahimi, yang memimpin pelaporan Misi-misi Penjaga Perdamaian (Peace Keeping Mission), mendesak perlunya kekuatan bersenjata PBB yang kuat dan sedia setiap waktu terjun ke area konflik (demands for a more robust UN Force, including combat ready standby units). Juga ada permintaan agar kekuatan regional berperan aktif mengatasi konflik dan menstabilkan keadaan regional, seperti peran Nigeria dalam konflik Sierra Leone, Australia di Timor Leste dan sebagainya.

Secara garis besar berdasarkan alasan-alasan intervensi dalam Resolusi Dewan Keamanan PBB umumnya berkaitan dengan tiga hal berikut:

1. Adanya bukti pembunuhan dan penganiayaan secara sengaja terhadap penduduk sipil, tawanan dan lain-lain warga masyarakat seperti kelompok-kelompok minoritas dalam suatu konflik.

2. Penolakan para pihak yang terlibat konflik, khususnya negara yang dianggap bermasalah, untuk mengizinkan akses-akses kegiatan kemanusiaan.

3. Adanya kekerasan dan ancaman kekerasan atau ancaman keamanan terhadap pekerja-pekerja kemanusiaan / pertolongan.

Sedangkan model intervensi biasanya bersifat darurat untuk pertolongan kemanusiaan yang mendesak bagi korban, pengungsi dan pekerja kemanusiaan. Model intervensi juga berbeda-beda, bisa langsung dibawah komando PBB, intervensi oleh kekuatan suatu negara atau beberapa negara regional dengan otoritas dari Dewan Keamanan PBB, atau intervensi tanpa dukungan resolusi PBB baik unilateral maupun multilateral.

Model lain intervensi, biasanya dalam bentuk pemberian jasa-jasa baik sebagai mediator untuk menengahi konflik. Model ini telah lama juga dikenal dalam hubungan internasional, biasanya sebagai praktek untuk mencegah konflik dan menghentikan konflik antar negara tidak berlanjut. Dalam kerangka diplomasi dan hukum internasional, biasanya hal ini sebagai bagian dari proses penyelesaian konflik secara damai (peaceful settlement). Walaupun kadang-kadang atau dibalik layar upaya mediator tidak sepenuhnya pasif netral, tetapi aktif bahkan memaksa pihak bertikai untuk maju atau ikut perundingan perdamaian bersama. Misalnya peran AS untuk mendorong Israel dan Mesir berdamai sering dilihat lebih sebagai tekanan AS agar para pihak berunding menuju perdamaian. Hal yang lebih terbuka dilakukan AS yang mengebom Yugoslavia (Serbia) selama sekitar 3 bulan untuk memaksa Serbia bersedia berunding dan juga menyerahkan pimpinan Yugoslavia yang bertanggungjawab terhadap pelanggaran HAM dalam masa konflik pecahnya Yugoslavia, seperti Slobodan Milosevic. Biasanya disebut sebagai mediator with muscle, pihak ketiga mediator dengan kekuatan.

Adanya intervensi internasional demikian, tidak terlepas dari adanya pergeseran dalam perspektif politik internasional, dimana aspek-aspek HAM makin kuat, makin menonjol dan makin diterima masyarakat internasional. Pada era saat ini isu kemanusiaan dan keselamatan 
individu makin diterima dan tidak lagi hanya fokus pada kepentingan-kepentingan dan norma negara sebagai aktor hubungan internasional. Hal ini menunjukkan makin kuatnya aspirasi terhadap penegakan nilai-nilai kemanusiaan dalam proses politik internasional dan hubungan internasional umumnya.

Walaupun, jika melihat praktek normatif hubungan antar bangsa dan Piagam PBB secara keseluruhan, tampak bahwa aspek kedaulatan, aspek non intervensi masih tampak menonjol. Penghargaan terhadap HAM dan masalah-masalah dasar kemanusiaan masih dilakukan melalui mekanisme negara dan tidak langsung serta merta tertuju pada individuindividu. Hal ini dapat dipahami, oleh karena pada waktu berdirinya PBB tahun 1945, ancaman perdamaian dunia terutama dilihat dari ada tidaknya konflik antar negara. Keamanan individu belum mendapat perhatian utama. Namun dengan adanya pergeseran pandangan mengenai sumber konflik dan berakhirnya perang dingin, tampak bahwa perdamaian dunia juga dapat terancam oleh adanya pelanggaran-pelanggaran HAM berat terhadap individu-individu; pembunuhan massal terhadap etnik tertentu, pengusiran penduduk oleh kelompok penduduk lain atau pemerintahannya sendiri.

Dengan demikian dapat dikatakan terdapat perubahan pandangan dari kecenderungan perspektif realist, dan state moralist ke perspektif kosmopolitan. Intervensi terhadap suatu negara untuk kemanusiaan mulai dapat diterima dan mendapat pembenaran masyarakat internasional. Walaupun hal ini masih menyisakan persoalan dan senantiasa akan menjadi perdebatan internasional tentang metode pelaksanaan, besar dan cakupan atau skala intervensi, dan pelaksana intervensi. Disamping itu, biasanya juga muncul persoalan terkait dengan mekanisme untuk menjaga objektivitas dan imparsialitas intervensi internasional. Batasannya cenderung abstrak dengan menekankan bahwa seharusnya intervensi tidak boleh menghancurkan martabat dan kondisi negara tersebut. Oleh karena prinsip kedaulatan negara dan prinsip non-intervensi secara umum masih berlaku dalam politik dan hubungan internasional. Meskipun praktek intervensi terhadap suatu negara dengan alasan-alasan tertentu telah diterima masyarakat internasional, tetapi model ini tidak berarti menggeser prinsip utama sebelumnya yaitu prinsip kedaulatan negara dan prinsip non intervensi dalam suatu permasalahan negara. Pergeseran ini lebih seperti perluasan penerimaan terhadap prinsip humanitarian intervention, selain tetap memegang prinsip kedaulatan dan non intervensi negara.

\section{Kesimpulan}

Masalah konflik intra negara dewasa ini menjadi satu perhatian dalam politik dan hubungan internasional. Perhatian internasional terhadap konflik demikian ini makin menguat seiring dengan adanya pergeseran pandangan masyarakat internasional yang makin menerima perspektif kosmopolitan. Perspektif kosmopolitan ini menekankan keselamatan individu dan warga masyarakat dibandingkan kehendak untuk menekankan kepentingan keutuhan dan keselamatan negara umumnya.

Pada masa lampau khususnya era perang dingin biasanya intervensi dilakukan oleh suatu negara atau kelompok negara dilakukan untuk menjaga lingkungan pengaruhnya (sphere of influence) dan menjaga stabilitas kelompok dan perimbangan kekuasaan dan pengaruh, seperti intervensi AS ke Vietnam, dan intervensi Uni Soviet ke Czechoslovakia. Intervensi ini lebih pada aspek politik dan pemerintahan untuk menjaga stabilitas politik internasional umumnya. Sedangkan intervensi pasca perang dingin cenderung dilakukan secara multilateral dan didorong oleh alasan-alasan kemanusiaan diatas alasan politik dan keamanan negara, yang kemudian disebut sebagai humanitarian intervention. Intervensi dapat dilakukan baik dengan model militer maupun non militer seperti bantuan ekonomi, kesehatan dan bantuan untuk mediasi dan lain-lainnya. 
Oleh karena prinsip kedaulatan negara dan prinsip non-intervensi secara umum masih berlaku dalam politik dan hubungan internasional, penerimaan terhadap intervensi kemanusiaan tampak tidak bersifat mengganti terhadap prinsip non intervensi sebelumnya. Jadi meskipun praktek intervensi terhadap suatu negara dengan alasan-alasan tertentu (kemanusiaan) telah diterima masyarakat internasional, tetapi model ini tidak berarti menghapus prinsip utama sebelumnya yaitu prinsip kedaulatan negara dan prinsip nonintervensi dalam suatu permasalahan negara. Pergeseran ini lebih seperti perluasan penerimaan terhadap prinsip humanitarian intervention, intervensi kemanusiaan selain tetap memegang prinsip kedaulatan dan non intervensi negara. 


\section{DAFTAR PUSTAKA}

\section{Buku}

Beits, Charles R.. 1991. "Sovereignty and Morality In International Affairs" dalam David Held (ed), Theory Today. California: Stanford University Press.

Kegley Jr., Charles W. Kegley Jr. \& Eugene R. Wittkopf. 1995. World Politics Trends And Transformation. New York: St. Martin Press.

Miall, Hugh, Oliver Ramsbotham and Tom Woodhouse. 1999. Contemporary Conflict Resolution, Cambridge: Polity Press/Blackwell Publisher.

Nye Jr., Joseph S. 1997. Understanding International Conflict: An Introduction to Theory and History. Second Ed. New York: Addison Wesley Longman.

Papp, Daniel S. 1997. Contemporary International Relations: Frameworks for Understanding. Boston, MA: Allyn and Bacon (Macmillan College Publishing Co.).

Wheeler, Nicholas J. and Alex J. Bellamy, 2001. "Humanitarian Intervention and World Politics" dalam John Baylis dan Steve Smith (Eds.), The Globalization of World Politics. Oxford: Oxford University Press.

Oxford Advanced Learner's Dictionary, 1989. Oxford: Oxford University Press.

\section{Jurnal}

Gourley, Catriona Gourley. 2000. "Partner Apart: Managing Civil Miltary Cooperation in Humanitarian Intervention", UN Disarmament Forum.

Halim, Omar. 2000. "Partisipasi Indonesia Dalam Operasi Pemeliharaan Perdamaian PBB: Pelajaran Yang Dapat Ditarik", Makalah Lokakarya Deplu RI, 8-10 Agustus.

Hirsch, Michael. 2000. "Calling All Regional -Cops", Foreign Affairs, November Desember 2000.

Hoffman, Michael H. 2000. " Peace Enforcement Action And Humanitarian Law: Emerging Rules For Interventional Armed Conflict”, ICRC Review, Volume 82, Maret.

Roberts, Adam. 2000. "Humanitarian Issues And Agencies as Triggers for Military Action", ICRC Review, Volume 82, March.

Tanner, Fred. 2000. "Conflict Prevention And Conflict Resolution: Limits of Multilateralism", International Review of the Red Cross, Vol.82, September. 